\title{
Assessing the suitability of student interactions from Moodle data logs as predictors of cross-curricular competencies
}

\author{
Santiago Iglesias-Pradas ，Carmen Ruiz-de-Azcárate , Ángel F. Agudo-Peregrina
}

\begin{abstract}
A B S T R A C T
In the past decades, online learning has transformed the educational landscape with the emergence of new ways to learn. This fact, together with recent changes in educational policy in Europe aiming to facilitate the incorporation of graduate students to the labor market, has provoked a shift on the delivery of instruction and on the role played by teachers and students, stressing the need for development of both basic and cross-curricular competencies. In parallel, the last years have witnessed the emergence of new educational disciplines that can take advantage of the information retrieved by technology-based online education in order to improve instruction, such as learning analytics.

This study explores the applicability of learning analytics for prediction of development of two crosscurricular competencies - teamwork and commitment - based on the analysis of Moodle interaction data logs in a Master's Degree program at Universidad a Distancia de Madrid (UDIMA) where the students were education professionals. The results from the study question the suitability of a general interaction-based approach and show no relation between online activity indicators and teamwork and commitment acquisition. The discussion of results includes multiple recommendations for further research on this topic.
\end{abstract}

\section{Introduction}

Online educational technologies have changed the classroom in blended-learning and online learning environments, with higher education teaching consisting primarily of online lectures, interactions and activities (Phillips, Maor, Preston, \& Cumming-Potvin, 2012). The implementation of Learning Management Systems (LMS) or Virtual Learning Environments (VLEs), and the interactions occurring in them, generate a wide array of data that some researchers relate positively to student effort (Campbell, DeBlois, \& Oblinger, 2007), performance (Macfadyen \& Dawson, 2012) and outcomes (Archer, Chetty, \& Prinsloo, 2014; Hrastinski, 2009). This informational phenomenon has given impulse to new areas of research on the relationship between academic performance and interaction data, as a way to achieve a better understanding of online learning (Romero \& Ventura, 2007).

In parallel, the European Credit Transfer and Accumulation System (ECTS) and the European Higher Education Area (EHEA) have made strong emphasis on the capital role of mobility and training in instructional competencies. However, the objectives of the EHEA go beyond knowledge acquisition and the application of such knowledge to professional life, and aims to incorporate student training to a holistic model which also includes the acquisition and development of generic, cross-curricular competencies. Nonetheless, the effective integration of these skills into the formal education framework is still a pending subject. As Cobo (2013) notes, "Today it is still a challenge for educational institutions (particularly the more conventional ones) to know how to measure, quantify and qualify these skills" (p. 81).

Therefore, institutions, teachers and learners are deeply concerned about the development of new tools and methods aiming to improve academic performance (Voogt \& Roblin, 2012) and help measuring and developing the competences demanded by the labor market (Zapata, 2010), while at the same time they are currently facing the financial crisis and grappling with the lack of educational and financial resources (Ibarra Sáiz \& Rodríguez Gómez, 2011).

In this state of affairs, and motivated by technological, pedagogical, political and economic drivers (Ferguson, 2012), Learning Analytics (LA) emerges as a field which allows teachers to accurately identify the needs of students and tailor instruction accordingly (Dyckhoff, Zielke, Bültmann, Chatti, \& Schroeder, 2012). By offering 
information in real time, LA can support immediate alterations, suggesting a model of curriculum that is more fluid and open to change (Johnson, Smith, Willis, Levine, \& Haywood, 2011).

One of the main objectives of LA is the interpretation and contextualization of the data for improved learning (Agudo-Peregrina, Iglesias-Pradas, Conde-González, \& Hernández-García, 2014; Siemens, 2013). In LA, this interpretation of data is generally based on collections of the traces that learners leave behind and on the use of those traces to improve learning (Duval, 2014).

Nevertheless, tracking students in a LMS poses a big challenge, since their databases store an overwhelming amount of data, but not all of them are meaningful for educational and pedagogical purposes (Anderson, 2003; Archer et al., 2014). Agudo-Peregrina et al. (2014) establish a theoretical and empirical basis for the application of LA techniques upon three different classifications of the interactions registered in a LMS: (1) agent-based interactions; (2) frequency of use-based interactions; and (3) participation mode-based interactions. In their study, the authors confirm the existence of significant relations between some types of interactions and student outcomes for the all of the three classifications.

This research considers the suitability of a similar approach to study the relation between the interactions occurring in a LMS and the development of cross-curricular competencies - more specifically, commitment and teamwork - and therefore proposes the following research questions:

R1. Can interactions extracted from LMS log data predict teamwork and commitment levels in online learning contexts?

R2. If so, what is the relative influence of the different types of interactions in the acquisition of commitment and teamwork in online learning?

This paper is structured as follows: Section 2 covers a literature review on learning analytics and cross-curricular competencies, namely teamwork and commitment; Section 3 presents the research methodology and sample characteristics; Section 4 shows the results from the empirical data analysis; in Section 5, the authors discuss the findings from the study, address its limitations and offer avenues of further research; finally, Section 6 summarizes the conclusions.

\section{Theoretical background}

\subsection{Increased knowledge by categorization of interactions in a LMS}

Students leave a data trail while they are interacting with others, with information and with institutions through different technologies (Siemens et al., 2011). LMS Redundant have the capability of retrieving data about students' activity, be it posts on forum discussions, access to contents, answers to quizzes or whichever other assessment methods available. These interactions, in formal education contexts, have become an essential part of electronic learning processes (Donnelly, 2010) since they are specifically designed to induce direct learning toward defined and shared learning objectives or outcomes (Anderson, 2003).

Prior studies, such as Long \& Siemens's (2011), point out that LMS are a data source that can help to predict students' academic achievement; Dawson, McWilliam, and Tan (2008) state that data about the number of times a student interacts with the learning system provide useful information about their participation, making it easier to guide students and improve their academic performance; Pascual-Miguel, Chaparro-Peláez, Hernández-García, and Iglesias-Pradas (2011) point at active interactions in message boards as potential indicators of learning; and Beer, Clark, and Jones (2010) and Macfadyen and Dawson (2012) prove the existence of behavioral patterns from the information about student interactions, and find a correlation of said interactions with final academic performance.

As Beer, Jones, and Clark (2009) note, interactions may be indicators for learning outcomes. Beer et al. (2009) explored the use of LMS usage data to identify potential indicators of effective learning, and came to the conclusion that there is a significant relation between staff interaction and student's final grade. In this sense, Agudo-Peregrina et al. (2014) confirm the positive correlation between different types of interactions and academic performance in distance learning, and suggest that they may be reliable variables to create predictive models of learning outcomes.

Agudo-Peregrina et al. (2014) maintain that interactions are the most basic unit of learning data in virtual learning environments for learning analytics, and that each of these interactions is represented by a data log record stored in the system's database. According to Agudo-Peregrina et al., there are three system-independent classifications of learning interactions in a LMS (Table 1).

As mentioned in Section 1, our study draws upon these three categorizations of educational interaction data and applies statistical analysis to explore the potential relation of these indicators and the development of cross-curricular competencies.

\subsection{The relevance of cross-curricular competency development in online learning}

Educational institutions and researchers are striving to promote cross-curricular competencies, especially inter-personal competencies (OECD, 2012). Inter-personal, cross-curricular competencies help students to interact with each other (Rodríguez Esteban, 2012), and this interaction is considered a fundamental pillar of learning and training (Zazo-Bello, Agudo-Peregrina, \& Calero-Ruiz, 2012).

Cross-curricular competencies can eventually be seen more as hard-skills than soft-skills (Cobo, 2013) and are essential for the integration of students in the labor market (Alonso, Fernández Rodríguez, \& Nyssen, 2009; Bayona Bohórquez \& Heredia Cruz, 2012; Corominas et al., 2006; González \& Wagenaar, 2003), a market that demands professionals able to work in teams in networked structures (Dragomirescu-Gaina \& Weber, 2013). Two of these competencies, commitment and teamwork, are critical for students to achieve professional success, as they relate to their ability to effectively collaborate from an individual and social standpoint, respectively (Palmer Pol, Montaño Moreno, \& Palou Oliver, 2009).

\subsubsection{Commitment}

From the student's perspective, commitment refers to "the active and responsible participation of the student in his or her learning process" (Ruiz, 2013, p. 32). From this definition, commitment has two different dimensions: the first is related to the degree of engagement of the student in the learning process, while the second includes aspects relative to responsibility and fulfillment of his or her learning activities. Therefore, commitment represents students' willingness for participation directed toward learning success achievement (Miller, Rycek, \& Fritson, 2011).

Student commitment is considered one of the best predictors of learning and personal development (Carini, Kuh, \& Klein, 2006), as well as of academic results (Coates, 2005; Kuh, 2009). The US National Survey of Student Engagement also emphasizes the relevance of commitment, not only as a predictor of academic achievement but also as essential for quality and attainment (National Survey of Student Engagement, 2013).

Committed students are characterized by their active involvement in course activities, and high levels of access to resources (Michinov, Brunot, Le Bohec, Juhel, \& Delaval, 2011), as well as autonomy in problem-solving tasks and active participation in teamwork activities (Ibarra Sáiz \& Rodríguez Gómez, 2011). 
Table 1

System-independent categorization of interactions (adapted from Agudo-Peregrina et al. (2014)).

\begin{tabular}{|c|c|c|}
\hline Classification variable & Focus & Type \\
\hline Agent & Who? & $\begin{array}{l}\text { - Student-student } \\
\text { - Student-teacher } \\
\text { - Student-content } \\
\text { - Student-system }\end{array}$ \\
\hline Frequency of use & How much? & $\begin{array}{l}\text { - Transmission of contents (most used) } \\
\text { - Creating class interactions and student assessment (moderately used) } \\
\text { - Assessing courses and teachers (rarely used) }\end{array}$ \\
\hline Participation mode & How? & $\begin{array}{l}\text { - Active } \\
\text { - Passive }\end{array}$ \\
\hline
\end{tabular}

Furthermore, according to Krause and Coates (2008) and Trowler (2010), active participation of students offers a measure of their commitment to learning and involvement in the learning community. Therefore, and taking into account the classification of interactions based on participation mode, we propose the following hypothesis:

H1a. The number of active interactions positively predicts commitment level.

As stated above, committed students actively take part in course activities and have high levels of access to course contents, and upon Agudo-Peregrina et al. (2014) classification, we posit that:

H1b. The number of transmission of content interactions positively predicts commitment level.

H1c. The number of interactions in moderately used activities creating class interactions and evaluating students - positively predicts commitment level.

Flow of information among students - and between students and teachers - strengthens the feeling of community in online learning scenarios (Correia \& Davis, 2007; Tinto, 1997) and it is one of the recommended strategies to enhance student commitment (Silva Cutiño, Pardo Gómez, \& Izquierdo Lao, 2013). From this, we also propose that:

H1d. The number of student-student interactions positively predicts commitment level.

H1e. The number of student-teacher interactions positively predicts commitment level.

Moreover, as mentioned earlier, committed students show high level of access to learning resources. Following this rationale, we posit that:

H1f. The number of student-content interactions positively predicts commitment level.

\subsubsection{Teamwork}

Teamwork is one of the most demanded competencies among recent graduates (Shapiro, Lauritzen, \& Irving, 2011). In the context of this study, teamwork is defined as "the knowledge, skills and attitudes (KSAs) [...] which enable individual team members to coordinate" (Baker, Salas, King, Battles, \& Barach, 2005, p. 186).

Teamwork comprises many different attributes - the KSAs. The acquisition and development of teamwork-related KSAs happens when there is communication, active participation, listening and understanding among the team members (Stevens \& Campion, 1994), and then it follows that:
H2a. The number of active interactions positively predicts teamwork development.

H2b. The number of passive interactions positively predicts teamwork development.

Besides, team goals are shaped through interactions among team members (Boekaerts \& Minnaert, 2006), and learning requires a continuous dialogue (Laurillard, 2002) and exchange of ideas (Zapata, 2010). Therefore, we propose that:

H2c. The number of student-student interactions positively predicts teamwork development.

H2d. The number of "creating class interactions" positively predicts teamwork development.

Teamwork and commitment are also closely related, as increases in intra-group interactions in collaborative learning have as a result an increase of student motivation and commitment. In organizational theory, team members are efficient and achieve team goals when they are committed (Viles, Jaca, Campos, Serrano, \& Santos, 2012); this statement holds true also in online learning contexts (Parmigiani, Cerri, Valentina, \& Ghezzi, 2010), and thus we posit that:

H3. Commitment and teamwork levels are positively related.

\section{Methodology}

\subsection{Sample and course description}

For this study, we selected the yearly online "Teaching and New Technologies" Master's Program at UDIMA. This specific group of participants had one distinctive characteristic: all of them are students of the Master's Degree, but they also are working as teachers at different institutions and knowledge areas in traditional in-class contexts. The average age of the students was 35.3 years old; only three of them had prior experience as students with virtual learning environments, and their knowledge of the Moodle platform as teachers did not exceed 3 years. Student cultural diversity is another distinctive characteristic of this Master's Program, with $64 \%$ of foreign students. The Master's Degree initially had 184 students, 69 of whom completed it and were asked to voluntarily participate in the study; from these, a total of 39 students - 27 female and 12 male students, $56.2 \%$ participation rate - decided to take part in the study.

This Master's Degree is directed toward teachers and researchers, and it aims to give adequate training in the design of educational programs and contents for e-learning and blended learning. The program consists of three modules - technologies for education, educational design in e-learning and b-learning, and communication tools 
- comprised of 8 mandatory courses and 2 elective courses - from a total of 7 possible elective courses - and the final Master's Thesis. Approximately $77 \%$ of the learning activities and assignments take place in the Moodle platform - the remaining $23 \%$ use other external web tools. The collaborative learning takes place mainly in Moodle message boards, although some external tools are also used - for instance, there are a few synchronous sessions in Blackboard Collaborate. Teachers have two ways to answer student questions and doubts: in Moodle message boards - there is one for each course unit, for a total of 80 message boards - and by telephone, on a designated time schedule.

Student assessment is mostly made via assignments and questionnaires in Moodle, but also in networked learning activities inside and outside of the learning platform, with a weight of $50 \%$ of the final grade; the remaining $50 \%$ of the grade is assessed in an exam taken at the University facilities at the end of the semester. There were no peer-assessment activities, and thus grading was performed solely by the instructors; non-graded self-assessment tests were also available, but their completion was optional.

\subsection{Instrument}

For interaction data extraction and categorization, we used the Moodle plug-in Interactions (Agudo-Peregrina et al., 2014). The output from this plug-in gives the total amount of interactions of each type - as defined by Agudo-Peregrina et al. (2014) - for each student from the Moodle log data table - data containing personal information were anonymized by a pre-processing module. The extraction selected recorded log data of student activity from both semesters of the 2012-2013 academic year.

A tool created by Evalsoft and theoretically and empirically validated in prior studies (Sancho Thomas et al., 2001) was used to measure competency levels. Prior research has confirmed the validity of the self-assessment to measure the acquisition and development of competencies (Lucas \& Baird, 2006); for Lucas and Baird (2006), the error in the measurements of student self-reports "did not severely limit its validity" (p. 42). Other authors like Carot, Conchado, Mora, \& Vila (2011) or Triadó, Aparicio-Chueca, and Elasri-Ejjaberi (2013) arrived at the same conclusion, and stated that self-assessment was a good method to obtain information about the level of competency acquisition in the case of higher education graduates.

The instrument consisted then of two questionnaires: (1) commitment is assessed using a four-point Likert scale of six elements with two dimensions: social/group compromise and ethical commitment and (2) teamwork is conceived as a "semantic differential" with ten levels, structured in six dimensions: "participatory attendance to group meetings", "brainstorming", "content searching and sharing", "contribution to cooperative group processes", "group member support and encouragement" and "consensus and acceptance of team rules of operation".

Finally, an identification data block was included in the questionnaire covering age, gender and years into online education. The total 39 questionnaires for the assessment of the commitment competency were delivered just after completion of the Master's program; however, only 27 valid responses $-69.2 \%$ of the total teamwork questionnaires were completed and returned.

\subsection{Method of analysis}

The analysis is divided into two parts: assessment of the competency measurement instrument, and analysis of the relation between each type of interaction and the level of competency acquisition of each student. Following Macfadyen and Dawson (2012) and Agudo-Peregrina et al. (2014) we performed a multiple regression analysis in order to assess predictive power of each categorization of interactions, total variance explained and goodnessof-fit of the model. In this multiple regression analysis we used the total number of interactions of each category as independent variables and the total score of each competency as dependent variable.

It must be noted that, according to Cohen (1988), and taking into account the small sample size, the predictive power of this exploratory analysis will be low, with a large effect size.

\section{Data analysis and results}

First, we observed the reliability of the two measurement instruments used for the self-reported development of competencies (Table 2). The results show high values in both competencies and a robust measure of teamwork and acceptable measure of commitment. Since all the items for each competency had the same scale, the sum of all items was assigned to each student for the multiple regression analysis.

The log file of interaction data consisted of a total of 386.640 classified records corresponding to the total activity of the participants in the different courses of the Master's Degree. It is worth noting that there were big differences in the number of interactions between students, as Table 3 shows.

From Table 3, the number of student-teacher interactions was excessively low, and there are very high differences between the least and the most active users. Interestingly enough, the ratio between passive and active interactions is near 10:1 and, contrary to the expected result, interactions related to transmission of contents were lower than the rest of interactions in the same classification.

Figs. 1-3 show the detailed dispersion diagrams of the different types of interactions and level of commitment acquisitions, while Fig. 4 shows the dispersion diagrams for teamwork acquisition levels grouped by type of interaction and Fig. 5 relates commitment and teamwork acquisition levels.

From Figs. 1-4 we observe that, in general, lower levels of interaction with the LMS correspond to lower levels of competency acquisition, although there is high dispersion in mid- and highranges of both competency levels. Fig. 5 shows that there are four different groups of students: three students (left part of the diagram) had lower commitment levels and moderate to low teamwork levels; two students (bottom right part of the diagram) showed high level of commitment but low teamwork levels); five students (top right) had high level of acquisition in both competencies; finally, the rest of students had mixed, moderate to high levels of acquisition of both competencies. Based on these differences, we performed a Mann-Whitney $U$-test between the first two groups - with lower levels of acquisition in at least one competency - and the other two groups, and we found significant differences $(p<0.001)$ between them regarding student-student interactions and creating class interactions. More interestingly, after observation of the students in the third group - higher levels of acquisition in both competencies - these students also showed lower levels of activity; therefore, we performed another comparison of means, but this time including them in the first group for comparison of means, and we found that the differences in both types of interactions remained significant at $p<0.001$.

Table 2

Descriptive statistics and reliability measures of competency development.

\begin{tabular}{lllll}
\hline & $N$ & Cronbach's alpha & Mean & Std. dev. \\
\hline Teamwork & 27 & 0.92 & 50.89 & 9.07 \\
Commitment & 39 & 0.70 & 22.54 & 1.59 \\
\hline
\end{tabular}


Table 3

Descriptive statistics of interactions (commitment).

\begin{tabular}{lrrrr}
\hline & Min. & Max. & \multicolumn{1}{c}{ Mean } & Std. dev. \\
\hline Agent & & & & \\
Student-student & 33 & 2824 & 754.13 & 682.75 \\
Student-teacher & 20 & 63 & 36.15 & 11.79 \\
Student-content & 366 & 4955 & 1665.38 & 1099.61 \\
Student-system & 492 & 8953 & 2105.28 & 1569.58 \\
Frequency of use & & & & \\
Transmission of contents & 180 & 1630 & 573.54 & 324.17 \\
Creating class interactions & 52 & 5492 & 1482.08 & 1322.59 \\
Student assessment & 403 & 3949 & 875.82 & 601.42 \\
Course and teacher assessment & 0 & 0 & 0.00 & 0.00 \\
Participation mode & & & & \\
Active & 123 & 1528 & 369.95 & 257.46 \\
Passive & 795 & 14,820 & 4205.74 & 3051.70 \\
\hline
\end{tabular}

We then proceeded to the multiple regression analysis, using a backwards multiple regression analysis. The criteria for elimination was a probability $p<0.1$ for the $F$-distribution. The results of the multiple regression are shown in Table 4.

From Table 4, not a single classification was considered valid for prediction of commitment or teamwork acquisition, and no relation was found between any of the indicators and level of competency. Thus, the results from the analysis did not support $\mathrm{H} 1 \mathrm{a}-\mathrm{f}$ and $\mathrm{H} 2 \mathrm{a}-\mathrm{d}$.

Finally, a correlation analysis between commitment and teamwork returned a value of $r^{2}=0.35(p=0.07)$, reflecting just a marginal relation between both variables. This result did not support H3. Table 5 summarizes the hypotheses testing results.

\section{Discussion}

Our study proposed the use of a classification of interactions from Moodle log databases which had already been tested for prediction of student performance in prior studies, and aimed to assess the validity of these classifications and the different indicators as predictors of acquisition levels of two different cross-curricular competencies: commitment and teamwork. This is a novel approach, since similar LA studies tend to focus on the relationship between LMS data log-based student interactions and academic performance, student outcomes or attrition rates - as noted by Agudo-Peregrina et al. (2014). In contrast to those studies, our research focuses on cross-curricular competency level as response variable, a topic that has not been explored from a learning analytics
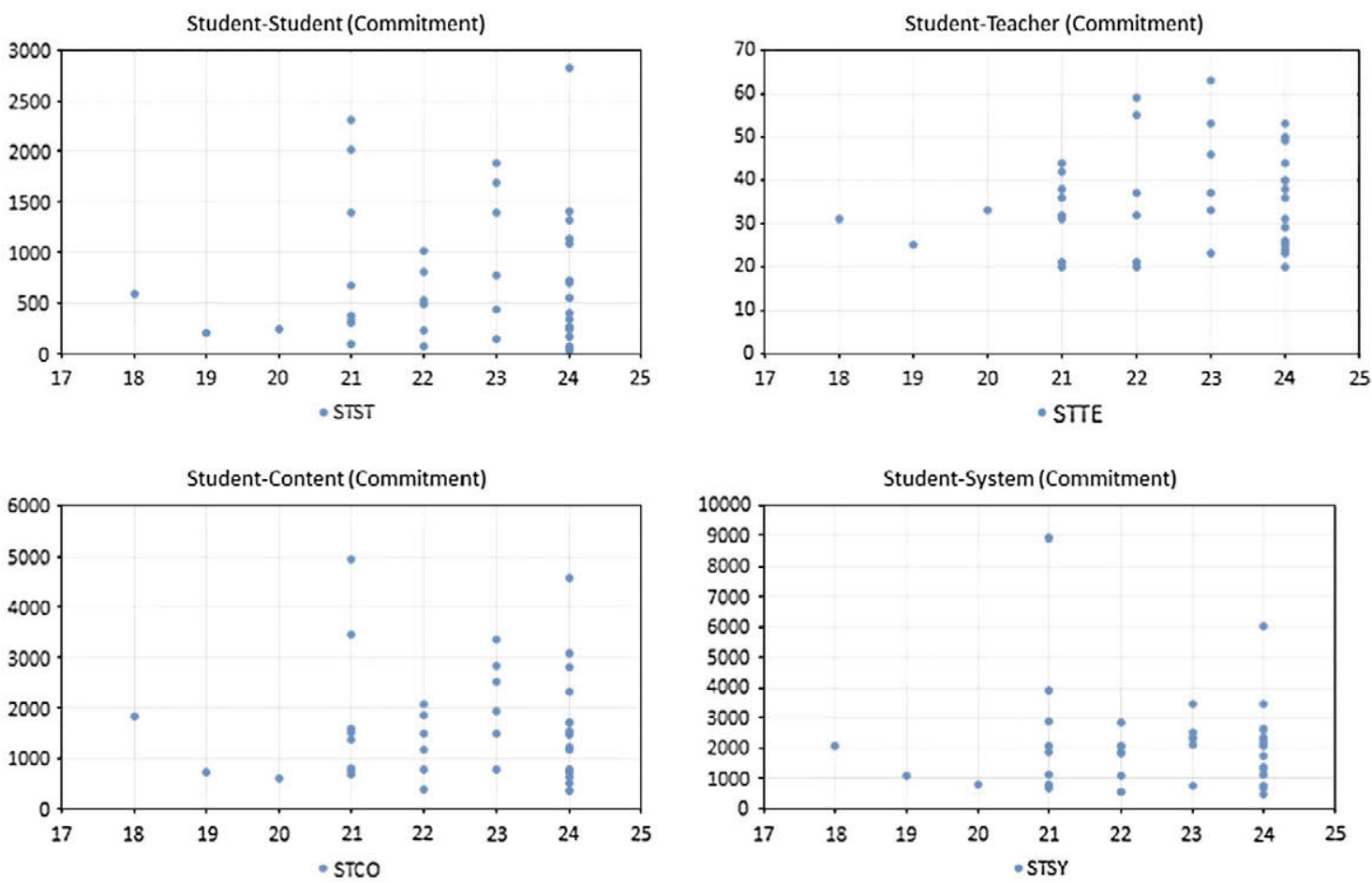

Fig. 1. Dispersion diagram of agent-based interactions vs. commitment acquisition.
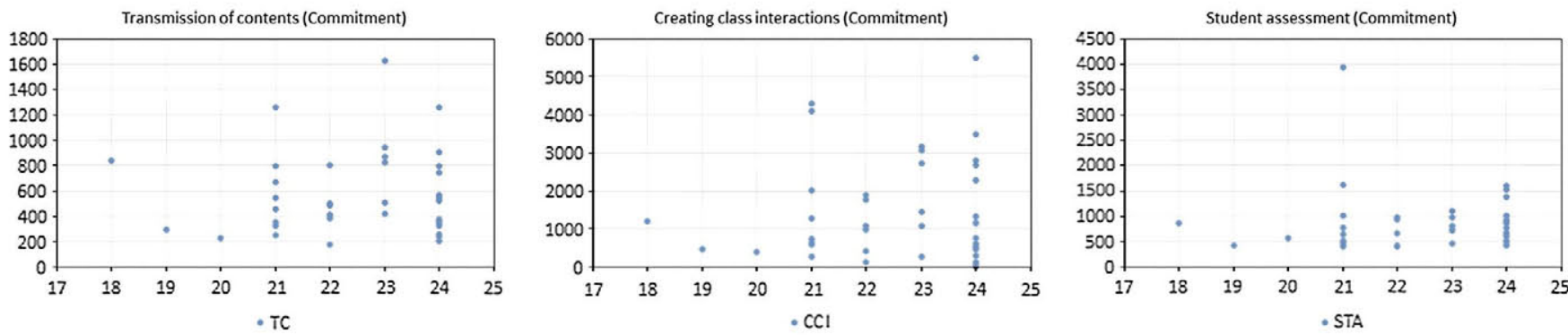

Fig. 2. Dispersion diagram of frequency of use-based interactions vs. commitment acquisition. 

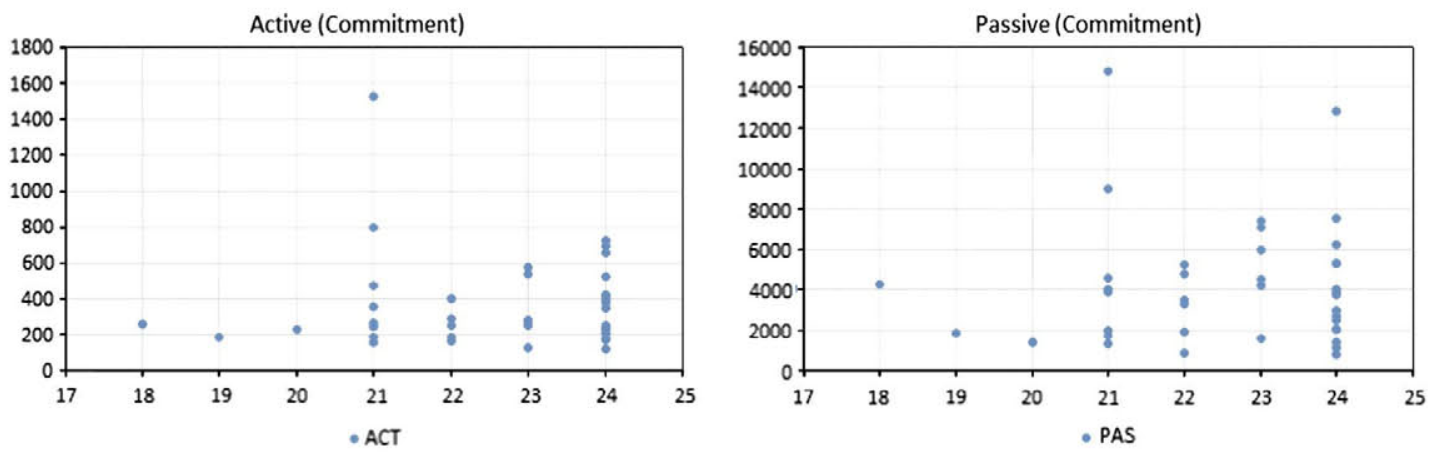

Fig. 3. Dispersion diagram of participation mode-based interactions vs. commitment acquisition.
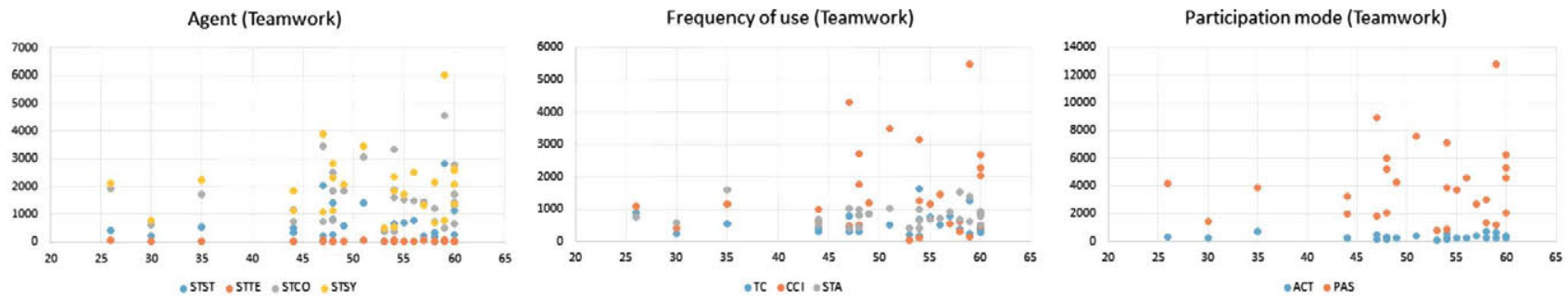

Fig. 4. Dispersion diagram of interactions vs. teamwork acquisition.

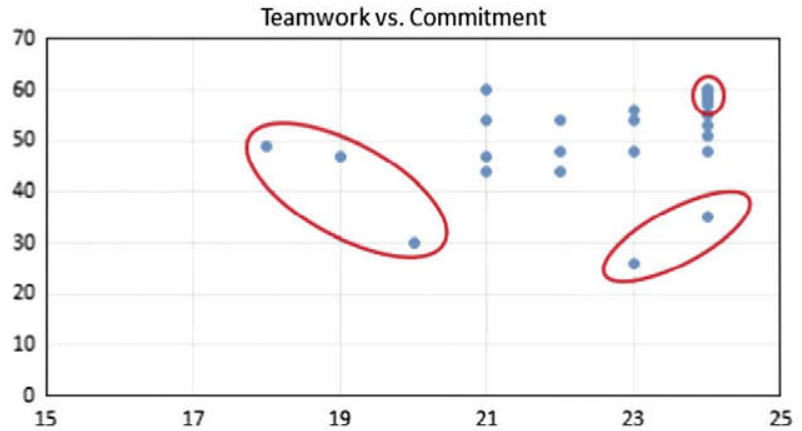

Fig. 5. Dispersion diagram of commitment vs. teamwork acquisition.

perspective but is extremely relevant in the current educational context, as explained in Sections 1 and 2.

The results of our analysis showed no relation whatsoever between interactions of any kind in the Learning Management System and the students' final level of teamwork competency. This was a surprising result; from a theoretical standpoint, and since teamwork is built through interaction among team members, we expected to find strong relation between student-student interactions, creating class interactions and active and passive interactions, on the one hand, and teamwork development, on the other hand. Although it should be confirmed by further research, this finding, together with the great dispersion found in the number of interactions between students (see Table 3), could indicate that a significant part of the students enrolled in the Master's Degree might have used a more autonomous and individual learning style, which would in turn hamper their ability to work as a group; thus, low interaction with peers, be it active or passive, could be an indicator of preference for more individual, self-directed learning styles which could hinder teamwork development.

Regarding commitment development, we also unexpectedly found no relation between any type of interaction and commitment levels. The measurement instrument for commitment included six items, five of which were related to the commitment to the group; therefore, analogously to the results achieved in the case of teamwork, a higher activity with educational contents and the system could be an indicator of preference for individual learning. In fact, this higher activity with computer interfaces might also have been reinforced by the grading system, since half of the grade required to pass each course depended on an individual exam.

It is also worth noting that Moodle logs reported an unusual low use of the platform regarding student-teacher interactions. This situation was considered an anomaly, and may have its cause in the existence of alternative ways to contact the instructors, such as telephone tutoring - the means preferred by students - and some online chat sessions. The inclusion of information related to this alternative ways of communication in the analysis could therefore have a significant impact on the relevance of some of the interactions - for example, student-teacher and active interactions - in competency acquisition.

Interestingly, our results might go in line with the findings of Davies and Graff (2005), who investigated the relation between online interactions and student grades and found that greater online interaction did not lead to significantly higher performance - or, in our case, competency levels - but that those who failed in their courses - in this case, with lower levels of competency acquisition - tended to interact less frequently.

Finally, we found only a weak, marginal relation between teamwork and commitment acquisition. Nevertheless, our analysis revealed different behaviors among students, with lower platform activity related to interaction with peers in students from both higher and lower acquisition levels. Therefore, these lower activity levels should be careful monitored to detect to which end of the spectrum the students might belong, in order to take corrective measures if needed.

\subsection{Limitations of the study and further research}

Despite the unexpected results from this study, our belief is that finding suitable predictors of competency development from a LA perspective is still critical to face the challenges derived from the present educational context, as presented in Section 1, so the rest 
Table 4

Final models after multiple backwards stepwise regression.

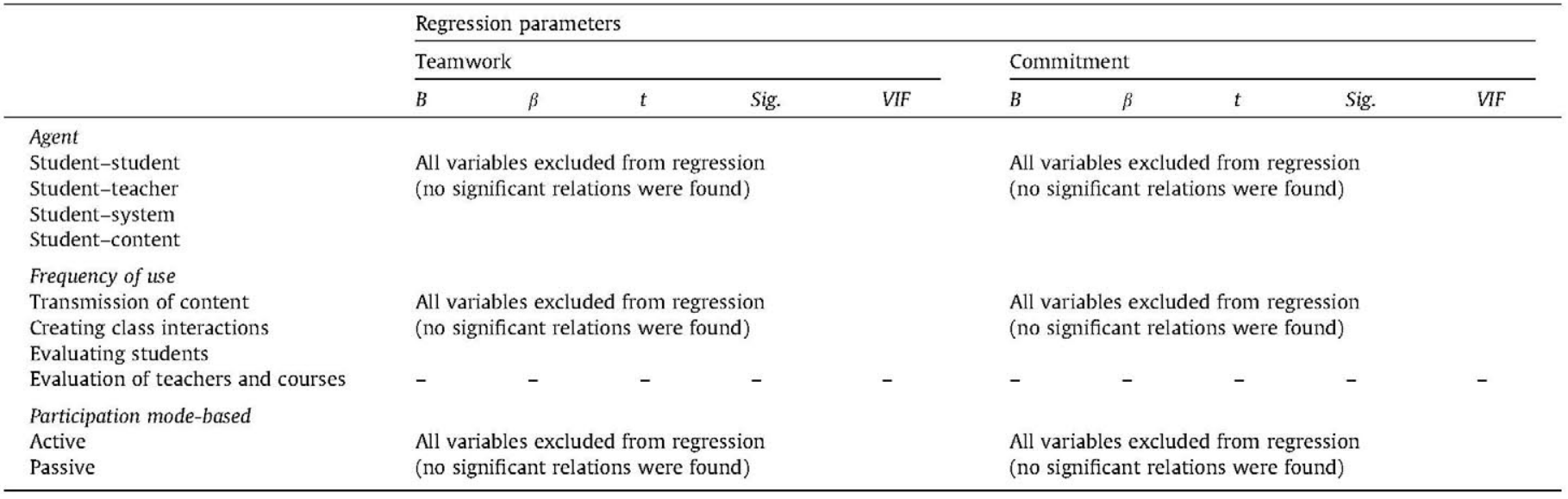

of this section will address our main concerns regarding this study in the hopes that future studies may find it easier to confirm or disconfirm the results from our analysis.

First of all, there are issues related to the sample and competencies used in this study. Apart from the difficulty to generalize the results from this study due to the reduced sample size, the characteristics of the sample may also have biased our results given the participants' profession, as teachers may have generally already developed teamwork skills and are demanded high grades of commitment when performing their tasks. A similar study using a more heterogeneous and less experienced sample might give different results more in line with the proposed hypotheses. Also, it has to be taken into account that the sample included students who also worked as teachers at UDIMA, as well as students who worked as teachers in other institutions - from primary to postgraduate education-; due to the fact that the respondents were questioned about their self-perceived competency levels, it is possible that the responses of the first group were affected by social desirability bias - in fact, a Mann-Whitney $U$-test revealed that students working at the same institution where this study was carried out rated their level of commitment slightly higher, but significant at $p<0.05$, than students working at other institutions.

Second, and although it had already been validated previously, there may be concerns about the measurement instrument that was selected to assess teamwork and commitment levels for various reasons: (a) the use of a scale with only four intervals for commitment showed little variation across responses, while the tenpoint semantic differential used for teamwork had greater variability, making it easier to assess individual analysis; therefore, we suggest the use of higher number of intervals for competency assessment; (b) we only measured competency acquisition at the end of the course; while this is a valid approach, it might be preferable to measure the variation of competency levels at different times in order to capture the actual degree of competency development - at least, we would suggest one measure at the beginning and other at the end of the course; and (c) while it is difficult to measure and assess the degree of commitment externally, the level of teamwork competency is subject to both internal - self-perception - and external measuring; that is, a more precise value of teamwork competency should include the individual's perception as well as his or her teammates'.

Third, even though we have justified the use of self-reported measures of competency levels in this study, and although they are the most widely used way to assess them, there is a need for development of additional means to measure competency acquisition automatically and more objectively, in order to effectively incorporate them to processes using learning analytics.

Fourth, as indicated in Section 3, the Master's Degree Program included activity in both Moodle and other external platforms as mentioned earlier, all of the synchronous communication took place in Blackboard Collaborate, for example. The increasing use of external platforms, as well as of informal networks (AgudoPeregrina et al., 2014; Hommes et al., 2012; Tempelaar, Rienties, \& Giesbers, 2015) makes it more difficult to perform this kind of studies due to the burdensome task of capturing and aggregating all the data from the different systems used by students, and also raises ethical concerns (Tempelaar et al., 2015). In this sense, recent initiatives like IMS's Caliper Analytics (http://www. imsglobal.org/caliper) or the Experience API (xAPI) (http:// www.adlnet.gov/tla/experience-api) aim to integrate data from both formal and informal contexts and could help overcome these limitations.

Table 5

Research hypotheses: summary of results.

\begin{tabular}{|c|c|c|c|c|}
\hline Hypothesis & Independent variable (predictor) & Direction & Dependent variable (response) & Supported (relation) \\
\hline $\mathrm{H} 1 \mathrm{a}$ & Active & $(+)$ & Commitment & No (ns.) \\
\hline $\mathrm{H} 1 \mathrm{~b}$ & Transmission of content & $(+)$ & Commitment & No (ns.) \\
\hline $\mathrm{H} 1 \mathrm{c}$ & Creating class interactions and evaluating students & $(+)$ & Commitment & No (ns.) \\
\hline H1d & Student-student & $(+)$ & Commitment & No (ns.) \\
\hline H1e & Student-teacher & $(+)$ & Commitment & No (ns.) \\
\hline H1f & Student-content & $(+)$ & Commitment & No (ns.) \\
\hline $\mathrm{H} 2 \mathrm{a}$ & Active & $(+)$ & Teamwork & No (ns.) \\
\hline $\mathrm{H} 2 \mathrm{~b}$ & Passive & $(+)$ & Teamwork & No (ns.) \\
\hline $\mathrm{H} 2 \mathrm{C}$ & Student-student & $(+)$ & Teamwork & No (ns.) \\
\hline $\mathrm{H} 2 \mathrm{~d}$ & Creating class interactions & $(+)$ & Teamwork & No (ns.) \\
\hline $\mathrm{H} 3$ & Commitment & $(+)$ & Teamwork & No (ns.) \\
\hline
\end{tabular}


Finally, our study show that Agudo-Peregrina et al.'s (2014) classification for interactions may fall short when describing teamwork related activities, since it does not take into consideration the collaborative nature of the task assigned to the student. Thus, we consider that future research on this topic should further refine those classifications so that each type of interaction may also be characterized depending on whether it has an individual or collaborative nature.

\section{Conclusion}

The goal of this exploratory study was to investigate whether a learning analytics approach could be suitable to find relevant predictors of two cross-curricular competences: teamwork and commitment. To achieve this objective, we used Agudo-Peregrina et al.'s (2014) system-independent characterization of online learning interactions in learning management systems, and assessed their potential relation to the former two competencies using data from an online Master's Degree at UDIMA.

The results of our analysis were nonetheless counterintuitive, showing no relation between interactions in the LMS and the level of competency acquisition. The limitations of our research suggest that our findings should be observed with caution, and therefore we provided numerous recommendations for future research on this topic.

\section{References}

Agudo-Peregrina, Á. F. Iglesias-Pradas, S., Conde-González, M. Á., \& HernándezGarcía, A. (2014). Can we predict success from log data in VLEs? Classification of interactions for learning analytics and their relation with performance in VLEsupported F2F and online learning. Computers in Human Behavior, 31, 542-550.

Alonso, L. E., Fernández Rodríguez, C. J., \& Nyssen, J. M. (2009). El debate sobre competencias. Una investigación cualitativa en torno a la educación superior y el mercado de trabajo en España. Madrid: Agencia Nacional de Evaluación de la Calidad-ANECA.

Anderson, T. (2003). Getting the mix right again: An updated and theoretical rationale for interaction. The International Review of Research in Open and Distance Learning, 4(2), 1-14

Archer, E., Chetty, Y. B., \& Prinsloo, P. (2014). Benchmarking the habits and behaviours of successful students: A case study of academic-business collaboration. The International Review of Research in Open and Distance Learning, 15(1).

Baker, D. P., Salas, E., King, H., Battles, J., \& Barach, P. (2005). The role of teamwork in the professional education of physicians: Current status and assessment recommendations. Joint Commission Journal on Quatity and Patient Safety, 31(4), 185-202

Bayona Bohórquez, J. A., \& Heredia Cruz, O. (2012). El concepto de equipo en la investigación sobre efectividad en equipos de trabajo. Estudios Gerenciales, 28(123), 121-132.

Beer, C., Clark, K., \& Jones, D. (2010). Indicators of engagement. Curriculum, Technology \& Transformation for an Unknown Future. Proceedings ascilite Sydney, $75-86$.

Beer, C., Jones, D., \& Clark, K. (2009). The indicators project identifying effective learning: Adoption, activity, grades and external factors. Same places, different spaces. Proceedings ascilite, 2009, 60-70. Auckland.

Boekaerts, M., \& Minnaert, A. (2006). Affective and motivational outcomes of working in collaborative groups. Educational Psychology, 26(2), 187-208.

Campbell, J. P., DeBlois, P. B., \& Oblinger, D. G. (2007). Academic analytics: A new tool for a new era. Educause Review, 42(4), 40-57.

Carini, R. M., Kuh, G. D., \& Klein, S. P. (2006). Student engagement and student learning: Testing the linkages. Research in Higher Education, 47(1), 1-32.

Carot, J. M., Conchado, A., Mora, J. G., \& Vila, L. E. (2011). La opinión de los graduados europeos sobre la universidad cinco años después de haber finalizado sus estudios. Papers. Revista de Sociologia, 96(4), 1269-1285.

Coates, H. (2005). The value of student engagement for higher education quality assurance. Quality in Higher Education, 11(1), 25-36.

Cobo, C. (2013). Skills for innovation: Envisioning an education that prepares for the changing world. Curriculum Journal, 24(1), 67-85.

Cohen, J. (1988). Statistical power analysis for the behavioral sciences (2nd ed.). Hillsdale, New York: Lawrence Erlbaum Associates.

Corominas, E., Tesouro, M., Capell, D., Teixidó, J., Pélach, J., \& Cortada, R. (2006). Percepciones del profesorado ante la incorporación de las competencias genéricas en la formación universitaria. Revista de Educación, 341, 301-336.

Correia, A. P., \& Davis, N. (2007). Comunidades de práctica complementarias: el equipo del programa y la comunidad en línea del curso. Teoría de la Educación. Educación y Cultura en la Sociedad de la Información, 8(3), 60-85.
Davies, J., \& Graff, M. (2005). Performance in e-learning: Online participation and student grades. British Jourmal of Educational Technology, 36(4), 657-663.

Dawson, S., McWilliam, E., \& Tan, J. P. L. (2008). Teaching Smarter: How mining ICT data can inform and improve learning and teaching practice. Proceedings of ascilite, 221-230. Melbourne, Australia.

Donnelly, R. (2010). Interaction analysis in a 'learning by doing' problem-based professional development context. Computers \& Education, 55(3), 1357-1366.

Dragomirescu-Gaina, C., \& Weber, A. (2013). Forecasting the Europe 2020 headline target on education and training. A panel data approach. European Commission, Joint Research Centre, Institute for the Protection and Security of the Citizen (IPSC). Luxembourg: Publications Office of the European Union.

Duval, E. (2014). Learning by numbers. Centro Superior para la Enseñanza Virtual (CSEV), 1-6.

Dyckhoff, A. L., Zielke, D., Bültmann, M., Chatti, M. A., \& Schroeder, U. (2012). Design and implementation of a learning analytics toolkit for teachers. Educational Technology \& Society, 15(3), 58-76.

Ferguson, R. (2012). Learning analytics: Drivers, developments and challenges. International Journal of Technology Enhanced Learning, 4(5), 304-317.

González, J., \& Wagenaar, R. (2003). Tuning Educational Structures in Europe. Final Report - Phase One. Bilbao: Universidad de Deusto.

Hommes, J., Rienties, B., de Grave, W., Bos, G., Schuwirth, L., \& Scherpbier, A. (2012) Visualising the invisible: A network approach to reveal the informal social side of student learning. Advances in Health Sciences Education, 17(5), 743-757.

Hrastinski, S. (2009). A theory of online learning as online participation. Computers \& Education, 52(1), 78-82.

Ibarra Sáiz, M. S. \& Rodríguez Gómez, G. (2011). Aprendizaje autónomo y trabajo en equipo: reflexiones desde la competencia percibida por los estudiantes universitarios. Revista Electrónica Interuniversitaria de Formación de Profesorado, 14(4), 73-85.

Johnson, L., Smith, R., Willis, H., Levine, A., \& Haywood, K. (2011). The 2011 Horizon Report. Austin, TX: The New Media Consortium.

Krause, K. L., \& Coates, H. (2008). Students' engagement in first-year university. Assessment \& Evaluation in Higher Education, 33(5), 493-505.

Kuh, G. D. (2009). The national survey of student engagement: Conceptual and empirical foundations. New Directions for Institutional Research, 2009(141), 5-20.

Laurillard, D. (2002). Rethinking teaching for the knowledge society. Educause Review, 37(1), 16-24.

Long, P., \& Siemens, G. (2011). Penetrating the fog: Analytics in learning and education. Educause Review, 46(5), 31-40.

Lucas, R. E.. \& Baird, B. M. (2006). Global self assessment. In M. Eid \& E. Diener (Eds.), Handbook of psychological measurement: A multimethod perspective (pp. 29-42). Washington, DC, US: American Psychological Association.

Macfadyen, L., \& Dawson, S. (2012). Numbers are not enough. Why e-learning analytics failed to inform an institutional strategic plan. Educational Technology \& Society, 15(3), 149-163.

Michinov, N., Brunot, S., Le Bohec, O., Juhel, J., \& Delaval, M. (2011). Procrastination, participation, and performance in online learning environments. Computers $\&$ Education, 56, 243-252.

Miller, R. L., Rycek, R. F., \& Fritson, K. (2011). The effects of high impact learning experiences on student engagement. Procedia - Social and Behavioral Sciences, $15,53-59$.

National Survey of Student Engagement (2013). A fresh look at student engagement. Annual results 2013. Bloomington, Indiana: Indiana University Center for Postsecondary Research.

OECD (2012). Better skills, better jobs, better lives: A strategic approach to skills policies. OECD Publishing.

Palmer Pol, A., Montaño Moreno, J. J., \& Palou Oliver, M. (2009). Las competencias genéricas en la educación superior. Estudio comparativo entre la opinión de empleadores y académicos. Psicothema, 21(3), 433-438.

Parmigiani, D., Cerri, R., Valentina, L., \& Ghezzi, E. (2010). Classes 2.0: How to improve learning environment in the classroom through ICT. <http://donmilanicolombo. wikischool.it/file.php/63/full_paper_classes_2_0_don_milani_15_01Parmigiani\% 20Cerri\%20Lupi\%20Ghezzi.pdf>.

Pascual-Miguel, F., Chaparro-Peláez, J., Hernández-García, A., \& Iglesias-Pradas, S. (2011). A characterisation of passive and active interactions and their influence on students' achievement using Moodle LMS logs. International Journal of Technology Enhanced Learning, 3(4), 403-414.

Phillips, R., Maor, D., Preston, G., \& Cumming-Potvin, W. (2012). Exploring learning analytics as indicators of study behaviour. In World conference on Educational Multimedia, Hypermedia and Telecommunications (EDMEDIA) (pp. 2861-2867).

Rodríguez Esteban, A. (2012). Las competencias en el Espacio Europeo de Educación Superior: tipologías. Humanismo y Trabajo Social, 6, 139-153.

Romero, C., \& Ventura, S. (2007). Educational data mining: A survey from 1995 to 2005. Expert Systems with Applications, 33(1), 135-146.

Ruiz, Y. A. (2013). Evaluación de competencias genéricas en la universidad. Estudio comparativo en entorno b-Learning y presencial. Tesis Doctoral. Madrid, Departamento de Métodos de Investigación y Diagnóstico en Educación, Universidad Complutense de Madrid.

Sancho Thomas, P., García García, M., Biencinto López, C., Carpintero Molina, F. Núñez Del Rio, C., Expósito Casas, E., et al. (2001). Enhancing Moodle to evaluate softskills in problem based learning approaches. In Experiencias innovadoras en la era digital (pp. 120-131). Cádiz: Bubok Publishing S.L..

Shapiro, H., Lauritzen, J. R. K., \& Irving, P. (2011). Emerging skills and competences - A transatlantic study. EU-US Study for the European Commission. DG-EAC.

Siemens, G. (2013). Learning analytics. The emergence of a discipline. American Behavioral Scientist, 57(10), 1380-1400. 
Siemens, G., Gasevic, D., Haythornthwaite, C., Dawson, S., Shum, S. B., Ferguson, R. et al. (2011). Open learning analytics: An integrated \& modularized platform. Proposal to design, implement and evaluate an open platform to integrate heterogeneous learning analytics techniques. Society for Learning Analytics Research.

Silva Cutiño, J., Pardo Gómez, M. E., \& Izquierdo Lao, J. M. (2013). Las Tecnologías de la Información y las Comunicaciones en los procesos formativos universitarios. Revista Colegio Universitario, 2(1), 77-84.

Stevens, M. J., \& Campion, M. A. (1994). The knowledge, skill, and ability requirements for teamwork: Implications for human resource management. Journal of Management, 20(2), 503-530.

Tempelaar, D. T., Rienties, B., \& Giesbers, B. (2015). In search for the most informative data for feedback generation: Learning analytics in a data-rich context. Computers in Human Behavior, 47, 157-167.

Tinto, V. (1997). Classrooms as communities. Journal of Higher Education, 68(6), $599-623$.

Triadó, X. M., Aparicio-Chueca, P., \& Elasri-Ejjaberi, A. (2013). La evaluación de competencias en la Educación Superior: el caso de un máster universitario. REIRE, Revista d'Innovació $i$ Recerca en Educació, 6(1), 34-52.

Trowler, V. (2010). Student engagement literature review. York: Higher Education Academy.

Viles, E., Jaca, C., Campos, J., Serrano, N., \& Santos, J. (2012). Evaluación de la competencia de trabajo en equipo en los grados de ingeniería. Dirección y Organización, 46, 67-75.

Voogt, J., \& Roblin, N. P. (2012). A comparative analysis of international frameworks for 21st century competences: Implications for national curriculum policies. Journal of Curriculum Studies, 44(3), 299-321.

Zapata, M. (2010). Evaluación de competencias en entornos virtuales de aprendizaje y docencia universitaria. Revista de la Educación a Distancia, $1,1-34$.

Zazo-Bello, S., Agudo-Peregrina, Á. F., \& Calero-Ruiz, J. M. (2012). Implantación y análisis de un sistema de respuesta interactiva en el aula. XX Congreso Universitario de Innovación Educativa en las Enseñanzas Técnicas (CUIEET 2012) (pp. 1-12). 